www.czasopisma.marszalek.com.pl/pl/10-15804/npw

\author{
АлЕКСАНДР ВЕРетИльНЫК \\ Uniwersytet Szczeciński \\ ORCID: https://orcid.org/0000-0001-5286-4466
}

\title{
Проблемы становления и развития государственности Республики Каракалпакстан
}

\section{Проблемы становления и развития государственности Республики Каракалпакстан}

\section{Аннотация}

Данная статья представляет собой исследование государственности Республики Каракалпакстан, ее интеграции с Узбекистаном и проблем, с которыми сталкиваются каракалпакские национальные движения, выступающие за ограничение вмешательства Ташкента во внутренние дела каракалпакского государства. Исследование можно считать актуальными и новаторским, так как в польских и европейских научных кругах проблемы Каракалпакстана являются недостаточно изученными. Развитие отношений со странами Средней Азии, обладающими большими запасами природных ископаемых, в том числе нефти и газа, является одним из приоритетов внешней политики Европейского Союза. Поэтому изучение региональных проблем и прогнозирование возможных военно-политических конфликтов в данном регионе мира, а также способов реагирования на них представляют собой особую актуальность для политических наук.

Ключевые слова: конституция, Каракалпакстан, права человека, Узбекистан, национальное самоопределение, интеграция, Средняя Азия 


\section{Problems of Formation and Development of Statehood of the Republic of Karakalpakstan}

\section{Abstract}

This article is a study of the statehood of the Republic of Karakalpakstan, its integration with Uzbekistan and the problems faced by the Karakalpak national movements. The study can be considered relevant and innovative, since the problems of Karakalpakstan are insufficiently studied in the Polish and European scientific community. The development of relations with the countries of Central Asia, which have large reserves of natural resources, including oil and gas, is one of the priorities of the foreign policy of the European Union. Therefore, the study of regional problems and prediction of possible military-political conflicts in this region of the world, and how to respond to them, is of particular relevance to the political sciences.

Keywords: Constitution, Karakalpakstan, human rights, Uzbekistan, national self-determination, integration, Central Asia

\section{Вступление}

$\mathrm{P}$ аспад Советского Союза в начале 90-х годов XX века многие исследователи на постсоветском пространстве называют «парадом суверенитетов» (Синцов, Битюцкий 2019, с. 59). После 70 лет своего существования тоталитарное советское государство предоставило покоренным народам право на самоопределение. Им воспользовались не только народы 15 союзных республик, но и народы проживавшие в национально-территориальных автономиях. Государственный суверенитет провозгласили Республика Татарстан, Республика Башкортостан, Чеченская Республика (Ичкерия), Марийская Республика (Марий Эл), Республика Калмыкия и др. республики ныне входящие в состав Российской Федерации, грузинские автономии Абхазия и Южная Осетия, Приднестровский регион Республики Молдова, Крым ${ }^{1}$, а также Каракалпакская АССР, входившая в состав Узбекской ССР.

Целями данного исследования являются: анализ становления государственности каракалпакского народа; анализ Конституции

1 С 2014 года Крым оккупирован и аннексирован Российской Федерацией. Международное сообщество считает аннексию незаконной и выступает за восстановление территориальной целостности Украины. 
Республики Каракалпакстан; анализ периода нахождения Республики Каракалпакстан в составе Республики Узбекистан; прогнозирование развития отношений между Республикой Каракалпакстан и Республикой Узбекистан после истечения срока действия межгосударственного договора от 1993 года о вхождении Республики Каракалпакстан в состав Узбекистана с правом выхода из него по истечению 20 лет.

\section{Становление каракалпакского государства}

Историк и исследователь Средней Азии Нурали Мингбаев в своей работе Каракалпакия: история образования пишет, что каракалпакская государственность берет свое начало с Ногайского ханства, которое было образовано в конце XIV века под руководством предводителя ногайцев (мангытов) Эдыгея (Мингбаев, 2017). К началу XVIII века живущие на берегах Сырдарьи каракалпаки сумели объединиться в единое национальное государство - Каракалпакское ханство. Его границы проходили по верхнему течению Сырдарьи и оно соседствовало с населенными калмыками землями Поволжья, Башкирским улусом и казахским Младшим жузом². Экспансия калмыков вынудила каракалпакское население бежать со своих земель, что привело к краху Каракалпакского ханства. Каракалпаки переселились к нижнему течению реки Сырдарья - на земли, которые позже вошли в состав Хивинского ханства ${ }^{3}$.

B XIX веке Россия начала военные походы в Среднюю Азию с целью расширить свое политическое, военное и торговое присутствие в регионе. Они были связаны с началом геополитического противостояния российской и британской империй, которое вошло в историю под названием «Большая игра» (Great game). Историк Марина Габдрашитова в статье Этапы Большой игры в Средней Азии отмечает, что конечной целью противостояния двух держав было установление контроля над Афганистаном (Габдрашитова, 2009). Британия продвигалась к его границам с юга и востока, со стороны своих владений в Индии, а Россия

\footnotetext{
2 Исторически сложившееся родоплеменное объединение казахов.

3 Другое название - Хорезм/Хорезмское государство.
} 
- с севера, захватывая территории среднеазиатских ханств. Катализатором, побудившим Россию активизировать экспансионистскую политику в регионе, по мнению историка, стало нападение Британии на Афганистан в 1838 году (начало первой англо-афганской войны).

В 1867 году Россия создала в Средней Азии Туркестанское генерал-губернаторство, в состав которого включила территории покоренного Кокандского ханства и земли отторгнутые у Бухарского эмирата. Таким образом она получила общую границу с Хивинским ханством, что привело к росту напряженности в отношениях двух стран и многочисленным пограничным конфликтам. Сложившаяся ситуация на границе и нежелание хивинской политической элиты занимать российскую сторону в «Большой игре» послужили для России поводом для вторжения в Хиву в 1873 году. Слабо вооруженная армия ханства

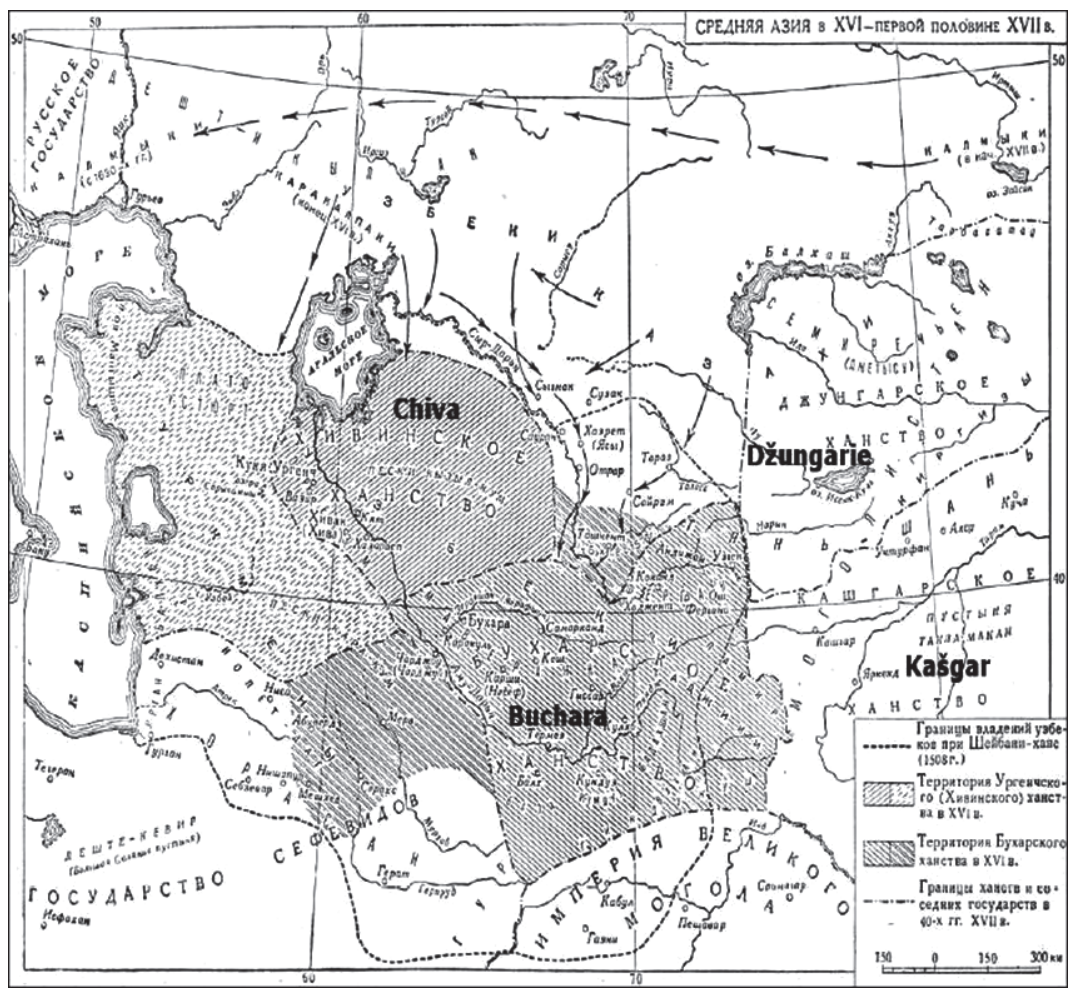

Карта Хивы. Источник: https://stanradar.com/news/full/4965-istorijakyrgyzstana-kokandskoe-hanstvo-glazami-russkih-issledovatelej.html 
и разобщенные отряды ополчения, состоявшие в том числе из каракалпаков, не смогли противостоять превосходящей их по численности и вооружениям российской армии, что привело к поражению Хивы. По итогам войны Хивинское ханство стало вассалом Российской империи, а его территория сократилась в три раза (Мингбаев, 2017).

Среди земель, отошедших России, оказались все земли населенные каракалпаками и кочевыми киргизами. Так каракалпаки стали российскими подданными. По данным Н. Мингбаева, их численность в Хивинском ханстве до его поражения в войне 1873 года составляла примерно 160 тысяч человек (Мингбаев, 2017).

Государственный переворот 1917 года привел к свержению монархического строя и началу гражданской войны в России. Ранее покоренные ею народы стали восстанавливать свои национальные государства (украинцы, поляки, финны, народы Балтии, Северного Кавказа, Закавказья и др.), воспользовавшись «правом наций на самоопределение» (Мингбаев, 2017), которое провозгласили большевики. Восстановили свою государственную независимость и среднеазиатские вассалы России - Бухарский эмират и Хива. Изменение политики большевиков и их переход в наступление на новообразованные национальные государства на всем пространстве бывший Российской империи осложнило процесс укрепления государственности этих стран. В 1920 году под предлогом поддержки местных революционеров, выступавших с социалистическими лозунгами, в Бухарский эмират и Хивинское ханство вторглись вооруженные формирования Советской России ${ }^{4}$. Сопротивление слабо вооруженных армий и ополчения было подавлено, а государственность Бухары и Хивы официально ликвидирована. Более 1 миллиона человек, преимущественно мусульмане опасавшиеся преследований за религиозные убеждения, сбежало из Средней Азии в Афганистан, Китай и Иран. На территории аннексированной Советской Россией Хивы в том же году была создана Хорезмская Народная Советская Республика.

4 Неофициальное название социалистического российского государства в период с 1917 по 1922 год. 
В 1924 году Союз Советских Социалистических Республик (образованный в 1922 году) приступил к разделу среднеазиатских республик по национально-территориальному признаку, мотивируя свою политику правом народов Средней Азии на создание национальных государств. В рамках реализации этой политики многонациональная Хорезмская республика была ликвидирована. Ее Ходжейлинский и Кунградский районы, населенные преимущественно каракалпаками, были объединены с Амударьинской областью и преобразованы в Каракалпакскую национальную область в составе России. Н. Мингбаев пишет, что советские историки представляли это событие как «историческую необходимость» и реализацию «вековой мечты [каракалпаков] о национальной государственности» (Мингбаев, 2017).

В руководстве Компартии не было единого мнения на счет того, в состав какой советской республики должны входить земли населенные каракалпаками, поэтому их несколько раз передавали из республики в республику. В 1925 году Каракалпакская автономная область была передана из состава РСФСР в состав Казахской АССР. В 1930 году Каракалпакская автономия была выведена из состава Казахской АССР и возвращена под управление РСФСР. В 1932 году статус Каракалпакской автономной области был повышен до автономной республики в составе РСФСР, а в 1936 году она окончательно была передана из состава РСФСР в состав Узбекской ССР, частью которой оставалась вплоть до распада СССР.

В 1990 году Верховный совет Каракалпакской АССР принял Декларацию о государственной независимости Каракалпакии 5 . Так в Средней Азии появилось независимое каракалпакское государство, подписавшее в 1993 году межгосударственный договор с Республикой Узбекистан. Согласно этому договору Каракалпакстан вошел в состав Узбекистана на правах автономной республики с правом выхода из него по истечении 20 лет после подписания договора.

${ }^{5}$ С 1992 года - Республика Каракалпакстан. 


\section{Анализ Конституции Республики Каракалпакстан}

Конституция независимого Каракалпакстана была принята 9 апреля 1993 года (Закон Республики Каракалпакстан....). Изменения вносились в 1994, 1995, 1997, 2003 и 2014 годах. Формально это делалось для улучшения нормативно-правовой базы республики, но оппозиция считает, что главной целью этих изменений было стремление реализовать планы центрального правительства Узбекистана, в которые входило лишение автономии возможности принимать любые самостоятельные решения.

Согласно статье 1 Конституции, «Каракалпакстан - суверенная демократическая республика, входящая в состав Республики Узбекистан. Названия государства «Республика Каракалпакстан» и «Каракалпакстан» равнозначны. Взаимные отношения Республики Узбекистан и Республики Каракалпакстан в рамках Конституции Республики Узбекистан регулируются договорами и соглашениями, заключенными между Республикой Узбекистан и Республикой Каракалпакстан. Республика Каракалпакстан обладает правом выхода из состава Республики Узбекистан на основании всеобщего референдума народа Каракалпакстан» (Конституция Республики Каракалпакстан...). Статья 3 гласит: «Республика Каракалпакстан [...] определяет систему органов государственной власти и управления, проводит политику, согласованную с политикой Республики Узбекистан [...]». Это означает, что Каракалпакстан, не смотря на государственный суверенитет, не проводит самостоятельной внешней и внутренней политики, а полностью подчиняет ее интересам Узбекистана, что, в свою очередь, противоречит другим статьям основного закона Республики Каракалпакстан, а именно: статье 7, которая гласит, что «государственная власть в Республике Каракалпакстан осуществляется в интересах народа [Каракалпакстана]» (а не Узбекистана) и статье 10, согласно которой «от имени народа Каракалпакстана может выступать только избранный им Жокаргы Кенес республики [Каракалпакстан]» (а не органы государственной власти Узбекистана).

Международным и внешнеэкономическим отношениям Каракалпакстана посвящена Глава IV Конституции Республики Каракалпакстан, 
которая имеет только одну статью (статья 17), что свидетельствует о полной политической и экономической зависимости Каракалпакстана от Узбекистана и об отсутствии у правительства Каракалпакстана стремления и политической воли проводить самостоятельную, хотя бы чисто репрезентативную, политику на международной арене, по примеру Шотландии (входящей в состав Соединенного королевства Великобритании и Северной Ирландии) или Иракского Курдистана, который, являясь автономией в составе Ирака, все же проявляет большую внешнеполитическую и внешнеэкономическую активность в регионе и за его пределами.

Каракалпакстан является парламентской республикой (в отличии от Узбекистана, форма правления которого - президентская республика). Статья 68 (Раздел пятый, глава XVII) гласит: «Высшим государственным представительным органом власти является Жокаргы Кенес Республики Каракалпакстан, осуществляющий законодательную власть». Жокаргы Кенес состоит из 65 депутатов, избираемых сроком на 5 лет (статья 69). Статья 70 основного закона перечисляет полномочия Жокаргы Кенес. Среди них: принятие Конституции Республики Каракалпакстан, внесение в нее изменений и дополнений; принятие законов Республики Каракалпакстан, внесение в них изменений и дополнений, толкование законов Республики Каракалпакстан; избрание Председателя Жокаргы Кенеса Республики Каракалпакстан и его заместителя; образование Президиума Жокаргы Кенеса Республики Каракалпакстан; назначение и освобождение от должности Председателя Совета Министров Республики Каракалпакстан по представлению Председателя Жокаргы Кенеса Республики Каракалпакстан, согласованному с Президентом Республики Узбекистан; назначение и освобождение от должности заместителей Председателя Совета Министров Республики Каракалпакстан и членов Совета Министров Республики Каракалпакстан, образование и упразднение министерств, государственных комитетов и других органов государственного управления Республики Каракалпакстан; избрание Комитета Конституционного надзора Республики Каракалпакстан, Верховного суда Республики

\footnotetext{
6 Национальное собрание, парламент.
} 
Каракалпакстан по гражданским делам, Верховного суда Республики Каракалпакстан по уголовным делам, Хозяйственного суда Республики Каракалпакстан; назначение и освобождение от должности, по представлению Президиума Жокаргы Кенеса Республики Каракалпакстан, согласованному с Генеральным прокурором Республики Узбекистан, Прокурора Республики Каракалпакстан; приостановление и отмена решений местных Советов народных депутатов; законодательное регулирование вопросов административно-территориального устройства; определение системы и полномочий республиканских и местных органов государственной власти; утверждение по представлению Совета Министров Республики Каракалпакстан Государственного бюджета Республики Каракалпакстан и отчетов о его исполнении; назначение выборов в Жокаргы Кенес Республики Каракалпакстан и местные представительные органы; образование Центральной избирательной комиссии; внесение в Конституционный суд Республики Узбекистан предложения о соответствии Конституции Республики Узбекистан актов высших органов государственной власти и управления Республики Узбекистан; осуществление парламентского контроля и иных полномочий, предусмотренных Конституцией (Конституиия Ресnублики Каракалпакстан...).

Эта статья Конституции Каракалпакстана является еще одним свидетельством ограниченности суверенитета Республики Каракалпакстан. Из нее следует, что все важные кадровые назначения власти республики должны согласовывать с правительством в Ташкенте.

Статья 80 (Глава XVIII) провозглашает Председателя Жокаргы Кенеса (спикера парламента) «руководителем Республики Каракалпакстан и высшим должностным лицом Республики Каракалпакстан». Председатель Жокаргы Кенеса избирается Жокаргы Кенесем только после согласования его кандидатуры с президентом Республики Узбекистан (статья 80). Эта статья Конституции Каракалпакстана, ровно как статья 3 и статья 79 дают основания утверждать, что отношения между Республикой Каракалпакстан и Республикой Узбекистан строятся не на принципах равенства субъектов межгосударственного договора от 1993 года (двух суверенных государств), а по формуле «центр-провинция», в которой Каракалпакстан выступает в роли 
полностью зависимой от центра (Ташкента) провинции, обладающей ограниченной автономией.

Анализ Конституции Республики Каракалпакстан позволяет утверждать, что внесенные в первую редакцию основного закона поправки (в 1994, 1995, 1997, 2003 и 2014 годах) фактически ликвидировали государственный суверенитет республики, лишили республиканские органы власти возможности проводить самостоятельную внутреннюю политику, выбирать и назначать руководителей республики и других высших должностных лиц, делегировав эти полномочия центральному правительству Узбекистана.

\section{Каракалпакстан в составе Узбекистана после 1993 года}

Оригинал межгосударственного договора, подписанного каракалпакской и узбекской сторонами в 1993 году, который регулирует отношения между двумя странами, засекречен и его нет в открытом доступе (Гущин, 2014).Это затрудняет выяснение сути договоренностей, которые были достигнуты между правительствами Каракалпакстана и Узбекистана. Невозможно также выяснить причину, по которой Республика Каракалпакстан вошла в состав Узбекистана на правах автономии, а не создала с Республикой Узбекистан конфедеративное государство, что позволило бы ей сохранить государственный суверенитет. По данным Александра Гущина, заместителя заведующего кафедрой стран постсоветского зарубежья при Российском государственном гуманитарном институте, после истечения срока действия договора между Каракалпакстаном и Узбекистаном в 2013 году его неоднократно переписывали «задним числом» (Гущин, 2014). Информации о содержании и актуальном положении данного договора нет даже на официальной интернет-странице Жокаргы Кенеса: www.parliamentrk. gov.uz. Это может свидетельствовать о стремлении нынешних органов власти Каракалпакстана скрывать от населения республики правду о договоренностях с узбекской стороной и не допустить проведения в стране референдума о независимости на основании статьи 1 Конституции Республики Каракалпакстан. 


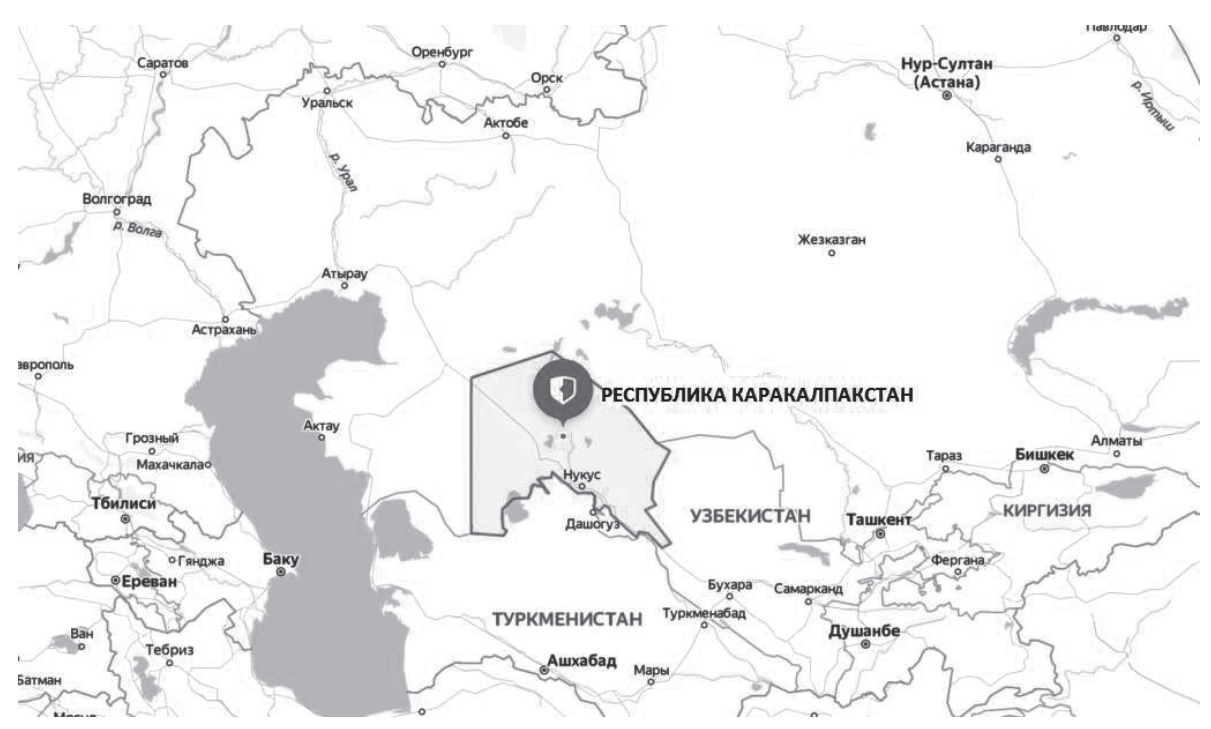

Каракалпакстан на карте Средней Азии. Источник: https://darsik.com/travel/2020/04/ pochti-vsyo-chto-vam-nuzhno-znat-pro-karakalpakiyu/.

За годы своей независимости Узбекистан, под руководством авторитарного президента ${ }^{7}$ Ислама Каримова, трансформировался в тоталитарное государство. Многие правозащитные организации, критиковали Ташкент за нарушение прав и свобод человека. «Репортеры без границ» сравнивали Каримова с президентом Зимбабве Робертом Мугабе и северокорейским лидером Ким Чем Ыном (Ислам Каримов ..., 2016). По данным Human Rights Watch «за 26 лет правления Каримова в Узбекистане по политически мотивированным обвинениям были арестованы тысячи человек, пытки в тюрьмах и в стенах милиции стали обыденным явлением; миллионы граждан, включая детей, принудительно направлялись на сбор хлопка в невыносимых условиях» (Узбекистан: скончался авторитарный президент..., 2016). В 2005 году по приказу Каримова военные расстреляли участников мирных акций протеста в городе Андижан, убив сотни (по некоторым данным тысячи)

7 Многие исследователи и правозащитники считали Каримова одним из самых жестоких диктаторов мира. 
человек (O’zbekiston: Hukumat qatliom...). По утверждению Стива Свердлова, исследователя Human Rights Watch по Центральной Азии, «Каримов правил посредством страха и построил систему, сочетающую в себе наихудшие нарушения прав человека: пытки, исчезновения, принудительный труд, систематическое уничтожение инакомыслия» (Узбекистан: скончался авторитарный президент..., 2016).

В докладе Human Rights Watch, посвященном ситуации в Узбекистане, говорится, что «начиная с 1992 года, Каримов развернул кампанию по искоренению всей политической оппозиции. Кампания приняла формы политически мотивированных арестов, избиений и притеснений, направленных преимущественно на ведущих членов нерелигиозных политических групп, представлявших оппозицию партии Каримова: партии «Бирлик» («Единство»), демократической партии «Эрк» («Свобода» или «Воля»), Исламской партии возрождения, «Адолат» («Справедливость»), Общества прав человека Узбекистана (ОПЧУ). Одних оппозиционеров посадили в тюрьму либо внесли в черные списки, других подвергли насильственному исчезновению, избиениям либо вынудили бежать из страны. На депутатов парламента Узбекистана, выступавших против консолидации власти в руках Каримова, были заведены уголовные дела и они были осуждены» (Узбекистан: скончался авторитарный президент..., 2016). Репрессиям подвергалось все население Узбекистана, включая жителей Республики Каракалпакстан, Конституция которой формально гласит, что «демократия в Республике Каракалпакстан базируется на общечеловеческих принципах, согласно которым высшей ценностью является человек, его жизнь, свобода, честь, достоинство и другие неотъемлемые права. Демократические права и свободы защищаются Конституцией и законами» (Конституция Республики Каракалпакстан, статья 13).

За годы пребывания Каракалпакстана в составе Узбекистана Конституция Республики Каракалпакстан, гарантирующая гражданам права и свободы, систематически нарушалась узбекской стороной, а правительство Каракалпакстана не предпринимало никаких усилий для создания механизмов, позволяющих защитить собственное население от репрессий со стороны узбекских властей. Основной закон страны, по-сути, стал фикцией. 
Неспособность властей обеспечить работу органов государственной власти и гарантировать населению соблюдение конституционных прав и свобод привели к росту протестных настроений в каракалпакском обществе и активизации политических групп, выступающих за проведение референдума о независимости Каракалпакстана. Наиболее заметными каракалпакскими движениями за независимость от Узбекистана являются Партия национального возрождения «Еркин Каракалпакстан» ${ }^{8}$ и Демократическая партия «Алга Каракалпакстан» ${ }^{9}$.

Анализ партийных материалов размещенных на официальном сайте ПНВ «Еркин Каракалпакстан» позволяет сделать вывод, что основными причинами, которые с 2007 года побудили движение требовать независимости Каракалпакстана, стали: полное подчинение республиканской элиты режиму в Ташкенте, ухудшение экономической и социальной ситуации в республике (при том, что она обладает большими запасами природных ископаемых, в том числе нефти и газа), репрессивная политика центрального правительства в отношении гражданских, политических и религиозных активистов Республики Каракалпакстан, экологические проблемы в регионе, связанные с высыханием Аральского моря. Лидеры партии обвиняют Каримова в геноциде каракалпакского народа посредством репрессий и принуждения к ассимиляции (Экстренное заявление ПНВКР, 2008).

Демократическая партия «Алга Каракалпакстан» заявила о себе в 2014 году, после нападения Российской Федерации на Украину и аннексии Крымского полуострова. Лидеры движения посчитали это событие знаковым для каракалпакского национального движения и не скрывали того, что рассчитывают на помощь Москвы (Волков, 2015), у которой с Узбекистаном сложились противоречивые отношения ${ }^{10}$. По данным Виталия Волкова, в распространенном в 2014 году заявлении лидеры «Алга Каракалпакстан» выступили с призывом «к демократическому развитию региона в форме независимой республики

8 Официальный сайт партии: http://freekarakalpak.blogspot.com/.

9 Официальный сайт партии: https://www.algakarakalpakstan.com/.

10 За годы независимости Ташкент неоднократно менял векторы своей внешней политики, сближаясь то с Россией, то с Западом (например участие в проамериканском интеграционном объединении ГУУАМ). 
или к присоединению Каракалпакстана к России или к Казахстану» (Волков, 2015). Позже, однако, Демократическая партия отказалась от поиска альтернативы независимости и начала критиковать Россию за попытку расколоть каракалпакское национальное движение и за поддержку Узбекистана. С чем связанно изменение политической программы партии и появление антироссийской риторики установить, анализируя данные из открытых источников, невозможно.

В 2019 году лидер Демократической партии «Алга Каракалпакстан» Аман Сагидуллаев заявил о создании «Правительства суверенной и независимой Республики Каракалпакстан в изгнании» (Решение о создании правительства..., 2019). По его данным, в создании Правительства в изгнании приняли участие « 278 депутатов, лидеров демократических партий, лидеров общественных и политических движений, представители культурных центров, объединений, правозащитники Республики Каракалпакстан, аксакалы, лидеры групп и гражданские активисты» (Там же). Решение создать такой орган Сагидуллаев мотивировал «беспрецедентным нарушением суверенитета независимой Республики Каракалпакстан» и «беззаконием оккупационного режима» Узбекистана (Там же).

\section{Проблемы национального движения Республики Каракалпакстан}

Лидеры каракалпакского национального движения, в том числе А. Сагидуллаев, подчеркивают, что движение за независимость Каракалпакстана - мирное ${ }^{11}$. В основном каракалпакские политики и активисты, выступающие за государственную независимость Каракалпакстана, действуют находясь в эмиграции. Проводят митинги, пикеты, обращаются в международные организации - в ООН, ОБСЕ и др. С одной стороны такая форма борьбы за политические идеалы в условиях тоталитарного государства, каким Узбекистан пока еще остается, не смотря на начатые новым президентом страны Шавкатом Мирзиёевым реформы, является наиболее оптимальной, учитывая

11 Https://www.algakarakalpakstan.com/apeal. 
готовность Ташкента к применению силы для подавления любых форм гражданского неповиновения (как это было в Андижане). Но с другой - отсутствие возможности политической агитации и борьбы за независимость (мирными средствами) в самом Каракалпакстане дают властям Узбекистана время на «окончательное решение каракалпакского вопроса». Под этим понятием следует подразумевать не только политику принуждения каракалпакского населения к ассимиляции, но также поощрение Ташкентом иммиграции этнических узбеков в каракалпакскую автономию и создание предпосылок для эмиграции каракалпаков в другие страны. Выступавший на конференции ОБСЕ в Варшаве в 2019 году каракалпакский активист Бахтияр Ниетуллаев заявил, что узбекские власти не ограничиваются этим и проводят насильственную стерилизацию каракалпакских женщин (Алпаут, 2019). Все это ведет к тому, что каракалпаки становятся в Республике Каракалпакстан меньшинством.

По данным А. Гущина, состоянием на 2014 год из Каракалпакстана эмигрировало более 250 тысяч этнических каракалпаков (Гущин, 2014) - в основном в соседний Казахстан. Всего в Каракалпакстане проживает 1 миллион 700 тысяч человек. Из них 32\% - каракалпаки, $32 \%$ - узбеки, остальные - казахи и представители других народов (Гущин, 2014). При сохранении нынешних темпов эмиграции Каракалпакстан рискует потерять не только свой суверенитет и независимость, но и даже ограниченную автономию, а борьба национальных движений за выход из состава Узбекистана потеряет смысл ввиду непоправимых этнодемографических изменений в Республике Каракалпакстан.

\section{Выводы}

В процессе исследования каракалпакского вопроса, анализа исторических источников, основного закона Республики Каракалпакстан и ее отношений с Узбекистаном мы пришли к выводу, что добровольное вхождение демократической парламентской республики Каракалпакстан в состав тоталитарного Узбекистана было исторической ошибкой правящей элиты Республики Каракалпакстан. Во вхождении Каракалпакстана в состав Узбекистана (тем более на правах автономии) не было 
реальной исторической и политической необходимости. Республика Каракалпакстан могла продолжить свое независимое существование без интеграции с Узбекистаном и стать первым в Средней Азии подлинно демократическим государством. Руководство Республики Каракалпакстан является соучастником преступлений режима И. Каримова совершенных в отношении народов Узбекистана и Каракалпакстана. Демографические проблемы и политика узбекского руководства в отношении Каракалпакстана создают риски для Республики Каракалпакстан, которые грозят ей потерей государственности. Политика центрального правительства в Ташкенте направлена на ликвидацию государственности и автономии Каракалпакстана.

По нашему убеждению, единственной возможностью для каракалпакского национального движения предотвратить ликвидацию государственности и автономии Каракалпакстана является форсирование сотрудничества с международными организациями, в том числе с ООН и ОБСЕ, которые должны оказать действенное международное давление на Узбекистан с целью принудить его отказаться от ныне проводимой политики в отношении каракалпакского народа, которую А. Сагидуллаев характеризует как «геноцид».

Будущее Каракалпакстана каракалпакский народ должен определить самостоятельно, в рамках все еще действующего законодательства Республики Каракалпакстан, которое допускает организацию и проведение всенародного референдума, если граждане Каракалпакстана сомневаются в выбранном правительством пути развития. Именно референдум может помочь каракалпакскому народу выбрать вектор развития и, после истечения срока важности межгосударственного договора с Республикой Узбекистан, определить на какой основе должны строиться отношения между странами дальше, решить, оставаться Каракалпакстану автономией в составе Узбекистана или начать развиваться как полноценный суверенный субъект международного права. И Узбекистан не в праве отказывать каракалпакскому народу в проведении такого референдума. 


\section{MGR OLEKSANDR VERETILNYK}

Instytut Nauk o Polityce i Bezpieczeństwie

Uniwersytet Szczeciński

ul. Krakowska 71/79, 71-017 Szczecin

oleksandr.veretilnyk@phd.usz.edu.pl

\section{Литература}

O'zbekiston: Hukumat qatliom uchun 10 yildan beri javob bermaydi. Pobrane z: https:// www.hrw.org/sites/default/files/related_material/Andijan\%20Press\%20Release\%20 -\%20Uzbek.pdf.

Алпаут, Р. (2019). Тоталитарные методы по отночению к этническим меньшинствам кочуют и по Узбекистану. Pobrane z: https://www.idelreal.org/a/30178922. html.

Волков, В. (2015). Независимый Каракалпакстан: мечта или политическая программа? Pobrane z: https://bitly.su/pigd.

Габдрашитова, М. (2009).Этапь «Большой игры» в Средней Азии. Pobrane z: https:// cyberleninka.ru/article/n/etapy-bolshoy-igry-v-sredney-azii/viewer.

Гущин, А. (2014). Каракалпакия: мечтатели-сепаратисты или путь к независимости? Pobrane z: http://politcom.ru/18300.html.

Закон Республики Каракалпакстан о принятии Конституиии Республики Каракалпакстан. Pobrane z: https://sovminrk.gov.uzru/pages/show/4.

Ислам Каримов строил новый Узбекистан железной рукой. (2016). Pobrane z: https:// www.bbc.com/russian/features-36976750.

Конституция Республики Каракалпакстан. Pobrane z: http://www.parliamentrk. gov.uz/ru/dokumenti/8/.

Marszałek-Kawa, J., Plecka, D. (red.). (2018). Leksykon wiedzy politologicznej. Toruń: Wydawnictwo Adam Marszałek.

Marszałek-Kawa, J., Plecka, D., Hołub, A. (red.). (2018). Social Security. Selected Aspects. Toruń: Wydawnictwo Adam Marszałek.

Мингбаев, Н. (2017). Каракалпакия: история образования. Pobrane z: https://caa-network.org/archives/10538.

Официальный сайт партии «Алга Каракалпакстан»: https://www.algakarakalpakstan.com/.

Официальный сайт партии «Еркин Каракалпакстан»: http://freekarakalpak.blogspot.com/.

Решение о создании правительства независимой и суверенной Республики Каракалпакстан в изгнании. (2019). Pobrane z: https://www.algakarakalpakstan.com/ karakalpakstan.

Решение о создании правительства Республики Каракалпакстан в изгнании. (2019). Pobrane z: https://www.algakarakalpakstan.com/karakalpakstan.

Российские спеислужбы, агенть ФСБ, уничтожают Движение за независимость Каракалпакстана. (2019). Pobrane z: https://bitly.su/AqpccOz. 
Синцов, Г., Битюцкий, Е. (2019). Роль и последствия «парадов суверенитетов» 1990-1991 г2. в становлении и развитии российской государственности. Pobrane z: https://cyberleninka.ru/article/n/rol-i-posledstviya-parada-suverenitetov -1990-1991-gg-v-stanovlenii-i-razvitii-rossiyskoy-gosudarstvennosti/viewer.

Узбекистан: скончался авторитарный президент страны Ислам Каримов. Его наследие - четверть века безжалостных репрессий. (2016). Pobrane z: https:// www.hrw.org/ru/news/2016/09/02/293744.

Экстренное заявление ПНВКР «Еркин Каракалпакстан». (2008). Pobrane z: http:// freekarakalpak.blogspot.com/2008/03/blog-post_11.html.

Эрдоган посетил могилу Каримова и почитал за упокой его души аяты из Корана. (2016). Pobrane z: https://saqofat.com/pages/viewpage.action?pageId=8192203. 